\title{
Can National Development Thrive Without Local Government's Constructive Input? Outlook of Nigeria, with Lessons for Africa
}

https://doi.org/10.36369/2616-9045/2021/v10i2a3

\section{IKEMEFUNA TAIRE PAUL OKUDOLO}

Postdoctoral Fellow in African Studies

North West University

34323503@nwu.ac.za

NTSIKELELO BENJAMIN BREAKFAST

Nelson Mandela University

ntsikelelo.breakfast@mandela.ac.za

\section{ITUMELENG MEKOA}

North-West University

Itumeleng.Mekoa@nwu.ac.za

\begin{abstract}
Satisfactory nationwide development without constructive local governments' input cannot manifest. Effectual local administrations are essential to discourage the production of deleterious interaction-effect of development. This paper evaluates published articles between 2010 and 2020 in the Nigerian context to comprehend what undermines impactful local governments' participation in national development to pinpoint lessons for African nations. It addresses how abject local governments in place do not support their positive involvement in national development. The intrinsic purpose of local government according to the classical theory's logic is the paper's theoretical foundation. Deriving from a literature review methodology, the paper proffers reform agendas to enhance the optimal efficacy of local administrations in the intergovernmental relations schemes for development in Africa from literature insights of the Nigerian situation. The analysis resonates the three thematic codes evolved from the classical theory's justification of local government: optimization of local governance, enhancement of local democracy, and facilitation of efficient local services delivery. It observes that implementation of ineffectual decentralization policies and lack of local autonomy are critical factors undermining optimum development in Nigeria, viz African countries. It concludes that effective decentralisation and local autonomy accentuates the centrality of local government in the national development trajectory.
\end{abstract}

Keywords: Local government, Classical theory, Decentralisation, Development, Intergovernmental relations 


\section{Introduction}

Our point of departure about contemporary effectual national development is the understanding that local governments' contribution in development as par its national outlook has been unequivocally postulated by the classical theorists of local government. These theorists note that every social systems' transformation, irrespective of the system of government and in any policy arena cannot be optimal if the local government do not perform its intrinsic purposes, and are not ensured a strategic place to aid the facilitation of positive developmental outcomes (Swilling, 2008; Scot, 2017; Dale, Robinson, King, Burch, Newell, Shaw \& Jost, 2020). The customary or classical theoretic notion of local government holds as a fundamental belief that strategic cum formal incorporation of local governments in the development process is sacrosanct. With the absorption of African local administrations - through decentralisation and in a manner not indicating subordination or suffocation of local autonomy - in the intergovernmental relations schemes of general development, there is the likelihood to produce optimal improvements to the social, economic, democratic and political advancement of society generally (Bradshaw, Breakfast \& Nomarwayi, 2016; Okudolo \& Onah, 2019).

A situation of alienation of the local political authorities in the development of their locales arouses the feeling that political elites at the higher echelons of government perhaps truly do not appreciate the value of functional local governments in the development trajectory (Bradshaw, Breakfast \& Nomarwayi, 2016; Okudolo \& Onah, 2019). Political elites, particularly in Africa, tend to trivialise the need for enacting effective decentralisation policies that allow local-municipal governments to play critical roles to actualise national development goals (Ladner \& Keuffer, 2018). For instance, in Nigeria, there is the obvious relegation of local governments in mitigating ensuing farmer-herders and internecine ethnic rivalry crises. Policy programmes to address these crises in Nigeria usually derive mostly from federal and state governments politicking without an iota of local administrations' input. Whilst the subsistent farmers and grassroots citizens mostly domiciled within local government jurisdictions constitute over 98 percent of victims from these crises, legislative practices to evolve development policies to cater for the real victims do not incorporate inputs of the local government closest to them.

Another instance across Africa of the relegation of local administrations' effort to advance development lay in the underutilisation of primary healthcare that is known to be more of a local government function (Okudolo \& Ojakorotu, 2021). The "health for all" objectives of the African Union (AU) to effectively surmount pandemics like COVID-19 has been unlikely with the obvious display of poor utilisation of local governments' primary care duties. Indeed, setting the template to accomplish qualitative development in the healthcare sector of Nigeria vis-a-vis Africa has become so much a dictated policy matrix by the higher tiers with little or no actual local governments' input. But, to well integrate 
local governments' primary healthcare efforts in the policymaking and implementation environment to overcome coronavirus, effective contact tracing, testing, vaccination and management of the COVID-19 globally is almost assured. Hence, the likelihood of instituting a developed healthcare system in Nigeria viz African nations or vanquishing of COVID-19 or any pandemic in the continent is more feasible with well-coordinated and productive intergovernmental health care relations with the local government primary care system.

Therefore, with some sense of certainty, one can assume that the abysmal development index of Africa - as regards the standard of living and general wellbeing of citizens - is a reflection of the ineffectual contribution or outright subordination of local government administrations in the entire development administration policy process circle. According to Brinkerhoff and Crosby (2002), the policy circle refers to the processes involved in the entire policy procedure from formulation to implementation, evaluation of outcomes and feedback into the agenda-setting stage again. George and Miller (2013) add that the policy circle framework covers problem identification from the political, social and economic sceneries; policy stakeholders' interactions on the problem; enunciation of possible solutions; resources allocation to implement possible solutions; policymaking enactment of laws and regulations; and finally full-scale implementation of authorised laws and regulations. The paper holds the belief that implemented development policies are destined to be failure-prone to produce underdevelopment if local administrations are not given pride of place in the policy process circle of their essence.

Accordingly, the essence of the formal inauguration of local government is defeated if the political institution is alienated. Transformation suffers if local political authorities that is expected to govern over local/grassroots development that constitutes the largest population ratio put together in a country is alienated in the development course due to pervasive and undue centralisation of power and authority, or tenacious application of the norms of concentrated development planning, policymaking and administration. In the paper, to justify the necessity for intergovernmental relations schemes that would support favourable decentralisation, we proceed by articulating the politico-historiographical trajectory of local self-government in Nigeria to validate the paper's underpinning theoretical framework.

\section{Debriefing Local Government in Nigeria}

The political sociology cum history of local government operations in Nigeria shows an underlying motif to disconnect the local political institution from active contribution to the modernisation and consolidation of development of the nation-state. That is, Nigeria's shortcomings in development are due to poor espousal of the decentralisation thesis and 
suffocation of local autonomy in the intergovernmental relations governance process. Unfortunately, political culture and conduct that do not endear local self-government and advance local autonomy often result in underutilisation of the local government administrations in the development process as well as worsen the grounding of a developmentally inclusive society.

Studies show that the socio-political and historiographical scenario of modern local government practices in Nigeria began under British colonial rule. The colonialism of Nigeria has been attributed to have heralded the modernisation of local government practice in the country (Okudolo, 2017; lyoha, 1996; Yahaya, 1981). This implies that some sort of local administration did exist before colonial rule at the various pre-colonial Nigerian societies that were amalgamated in 1914 by fiat of British colonialism. According to Okonjo (1974), the adoption of Indirect Rule by the British colonial government was the formal policy that erected modern local governance practice in Nigeria, while at the same time dismantling the pre-colonial cultural and traditional local governance system. Before the Lyttleton Constitution of 1954 which laid the foundation of Nigeria as a federal system, intergovernmental relations with local governments were built on unitary principles. This implies that local administrations were considered as field agencies of the central colonial government to operate by deconcentration and delegation. However, what the 1954 Lyttleton Constitution merely did was to change the pattern of the prior hierarchy of intergovernmental relations with local administrations to one in which the local institutions were now relegated under regional governments' legislative control and no more under the dictate of the central government. It is to be noted, however, that Nigerian local governments did not enjoy local autonomy under the federal Lyttleton Constitution despite being relegated under the regional governments.

As correctly observed by Yahaya (1989), the character of federal-state-local intergovernmental relations towards holistic and inclusive development of the Nigerian state was overtly driven by the desire to undermine local autonomy. For instance, the socalled local government reform upsurge of the 1950s did not ensure decentralisation but instead deepened deconcentration and delegation even though Nigeria had become a federation. Local autonomy suffered gravely during this epochal trajectory based on rash inter-party politics and decimating regional governments' squabbles to outdo one another that assumed violent worrisome dimensions. Yahaya (1989: 233) puts it succinctly that Nigeria's 1950s reforms of the local governance system mirrored the "prevailing network of class and factional alliances at the regions" and that such a philosophy permeated the whole layer of intergovernmental relations and inter-party relations for national development throughout the country. This explains the unusually large numbers and varying systems of local administrative structures that were put in place at the time. During this period, the Northern Region retained the Native Authority System, while the Eastern and Western Regions opted for multi-layered local government structures such as 
establishing county-municipal-local council stratum, emphasising political representation. What is to be noted is that despite the structure of local administration being practiced during the early period after Nigeria's Independence in 1960, the local government institutions continue to serve more of parochial interests of political elites especially at the region/state levels (Gboyega, 1987). One can thus imagine that "by 1960 there were 107 county councils, 2 municipal councils and 870 local councils in Eastern Nigeria alone" (cited from Yahaya, 1989: 237) that were largely unfit to be called a tier, and also grossly lacking autonomy to contribute meaningfully to grassroots development how much more the entire country's socio-economic and political transformation.

According to Iyoha (1996), the military's reorganisation or reform of Nigeria's local government system tagged the 1976 Local Government Reform aims at enhancing decentralisation and local autonomy. One notable ideal espoused by the 1976 reform is that the local governments are now regarded as the third tier of government in the Nigerian federation. The implied meaning of a third tier is that local government is an independent organ of government supposedly governed by locally elected officials. Meaning that the 1976 reform aligned with the decentralisation thesis which surmises that devolution by constitutional demarcations, not deconcentration or delegation, should define local government operations (Aghayere, 1997). Thus, the 1976 reform guideline advocated that Nigerian local governments would be operated by elected representatives established by constitutional dictates to exercise specific powers and have substantial control over local affairs, as well as, enjoy constitutional backing to direct staff matters, institutional policymaking and financial earnings cum expenditures directed towards the provision of services within local jurisdictions (Olowu, 1981). The reform also projected for local government is to enjoy autonomy to decide and execute projects entitled by law to it in which local resourcefulness and knowledge of local circumstances and needs are necessary to help accomplish optimal overall and inclusive national development (Ibaba, 2011; Atakpa, Ocheni \& Nwankwo, 2012).

It is to be stressed that the framers of the 1979 and 1999 Constitutions of Nigeria integrated the ideals of the 1976 local government reform into the legal documents particularly regarding enhancing decentralisation and local autonomy (Akpan \& Ekanem, 2013). On its part, the 1979 Constitution (which midwife the Second Republic 1979-1983 of Nigeria) guaranteed the system of local government that will exist in every state under Section 7(1) of the Constitution. That proviso approves that only the system of local government by democratically elected officials are to be recognised. Section 7(6) of the 1979 Constitution also provided for statutory allocation of public revenue to local government councils in the federation and permits local elected leaders to expend revenues for facilitating local services and public utilities provision. The Constitution also listed Functions of Local Governments in its Fourth Schedule. Also, by the stipulations of Section 7 of the 1999 Constitution, local government was recognised as the third tier of 
government and the system of democratically constituted local government system was guaranteed under the law (Awotokun, 2005). Section 7(1) of the 1999 Constitution reads: "The system of local government councils by democratically elected local government councils is under this Constitution guaranteed; and accordingly; the State Government shall, subject to Section 8, ensure their existence under a law which provides for their establishment, structure, composition, finance and function".

At the moment, Nigeria is operating her Fourth Republic which was inaugurated on May 29, 1999, with 774 constitutionally recognised local government councils. The 1999 Constitution which is to midwife the Fourth Republic provides for local government functions under the Fourth Schedule and provides for revenue sources for local administrations under Section $162(5)(6)(7)$ \& (8). Given the decadent developmental status of the Nigerian state and existence of undeveloped grassroots jurisdictions in terms of physical outlook and dysfunctional cum pitiable public utilities/infrastructure availability which ends up having national echoes, examination of scholarly explanations for such negative growth indicators and how to overcome them on the throes of the ongoing federal-state-local intergovernmental relations schemes is a worthy intellectual engagement.

\section{Meta-Theoretical Underpinning of the Paper}

The meta-theory of the paper is anchored on critical philosophical postulations of the classical theorists' ideas of the rationale for local government. This classical theoretical supposition became popular at the time experiencing bourgeoning attention to the debate over how to fast track national development in the middle of the $19^{\text {th }}$ century. The question of why formalise local government was trendy in scholarship during the period. In the paper, classical theory should be understood as an abstract generalising about the inevitability of local government in actualising comprehensive development process (Andrew \& Goldsmith, 1998). However, it is important to note from the classical times that local government is conceived as a political tier of a nation - whether unitary, monarchical, or federal system- as the least or bottommost subdivision of government recognised by public law to exact ample control over local affairs, including the authority to enforce taxes and expend same on sanctioned purposes.

According to Ola (1984), the United Nations Office of Public Administration notes that ideally, the local government governing body is ordinarily elected or otherwise locally selected. Being a governmental tier in its own right, consequently, Whalen (1960) has the belief that local government state qua state possesses these features: A given territory, population, institutional structures such as the legislature, executive and judicial systems for administration of the area; a range of power and functions authorised by 
decentralisation by devolution or deconcentration or delegation, and also some measure of autonomy within the limits of reasonability. Thus, local government is conceived as government at the local level established by law to exercise specific powers within defined areas and initiate and direct the provision of services and to determine and implement projects to complement the activities of the higher tier governments in development. Also, local government operate specifically for local areas by ensuring that local initiative and response to local needs and conditions are maximized (the above definition is rephrased from that given by The 1976 Local Government Reform Guidelines Report Document of the Federal Republic of Nigeria; cited from Aghayere, 1999, p. 39). The implication of the above-stated definition is that the classical theorists also hold the belief that local government is supposedly a quasi-autonomous political organ. The political structure is expected to cooperate within a mutual-interdependent intergovernmental relations matrix for national development.

Given the above definition, the classical theorists' answer to the question of why establish local government resonates with John Stuart Mill's utilitarian philosophy which has since been used by theorists to justify local government (Mill, 1861). John Stuart Mill (1806 1873) had philosophised that the utilitarian philosophy articulates the principle of utility as any action, institution, or act that produces the "greatest happiness of the greatest good". Therefore, by deductive reasoning, John Stuart Mill holds that local governments are the best institutions that can produce the greatest developmental happiness of the greatest developmental good within grassroots jurisdictions and through the intergovernmental relations process for development that will permeate the national level (Gray \& Jenkins, 1999). In other words, higher tiers need to embrace decentralisation transfers to local administrations and grant requisite local self-government or local autonomy because such will produce the greatest happiness and good to the overall development of a nation-state.

From the aforesaid, decentralisation by devolution refers to allocation of powers, functions, political, administrative and fiscal autonomy to local government authorities by constitutional codification as expressed in the intergovernmental relations processes. On the other hand, decentralisation by deconcentration assumes that local administrations exist as field agents of the higher tiers and that their function, administration, fiscal expenditures and entire being is at the behest of the higher governmental authority under whose legislative competency the local government falls. We hold the view in concord with Romeo (2012), Holden, Linnerud and Banister (2017), and other notable authorities on local government topic that at the heart of the notion of the classical theory of local government is envisaged greater decentralisation and more measure of local autonomy to be able to assert itself as a tier. For this reason, classical theorists of local government such as Sharpe (1970), Fieldman and Goldrick (1970), Whalen (1960), Mackenzie (1961), and others concur that local government will serve the intergovernmental relations 
development trajectory optimally, with functional decentralisation policies in place as well as enjoy requisite autonomy in place, by the performance of three main functions. These functions are optimization of local governance viz effective local participatory governance; enhancement of local democracy viz national democratisation; and facilitation of local service delivery viz expediting the good quality life and living of citizens.

By way of synopsis, the classical theory of local government justifies the necessity of this political institution for maximum production of inclusive national development on three grounds. The first ground is that local government is the best possible institution to get local citizens involved in the management of public affairs particularly via grassroots democracy. The second ground is that it is the most suitable grassroots agent of the government to ensure effective mobilisation of local area resources to optimize local governance vis-à-vis optimisation of national good governance. The third ground is because the closeness of local government to the grassroots helps to ensure quick, equitable and prompt response cum delivery of needed social services to local citizens and thereby facilitate national development. Fieldman and Goldrick (1970) sum it up succinctly that local government is essential in the development administration of the entire country because it serves these purposes: local government can easily gauge its citizens' wants since they best know the grassroots peculiarities and are therefore well-positioned to better understand the locality's desires, needs and aspirations; Local government's understanding of its citizens' wants empower them to have the higher aptitude to direct local undertakings to actualise these aspirations; and the closeness of local government to the grassroots guarantees they have a far more viable span of control to efficiently deliver local services and capacity to effectively address local affairs. The span of direct contribution to the development of the higher tiers in local jurisdictions is usually limited because they do not enjoy proximity to the grassroots setting. However, this strongly depends on ensuring that effective decentralisation programmes are transferred to local administrations to execute and that optimum local autonomy or local self-government for developmental advancement exists.

\section{Problem Statement}

Empirically, local jurisdictions in Nigeria - reflecting across Africa - are said to be undeveloped, lacking many fundamental cum functional public utilities. In Nigeria, local administrations hardly formulate efficient by-laws and usually do not have an efficient local taxing system because their tax collection processes are not standardised thereby leading easily to political corruption and mismanagement of public revenues by collaboration of local representatives with particularly state-based bureaucrats (Okudolo, 2018). Indeed, Nigeria's inefficient local finances system, revenue generation and expenditure patterns explain why that level of government under-contributes to national 
economic development. It is also a known fact that the state tiers in Nigeria often deny their local government the political autonomy for them to vote persons of their choices to superintend local affairs (Akpan \& Ekanem, 2013). Ultimately, denial of local selfgovernment in Nigeria does not encourage effective decentralisation in the course of the intergovernmental relations for the country-wide development. And the negative political culture and behaviour thrust upon the local government jurisdictions in Nigeria by especially the state governments continue to lead to the undermining of democratisation of the country, wasted public resources utilisation for growth and ultimately estrangement of inclusive development.

There is perhaps the truth that local administrations in Nigeria from the outset are marginalised, demoralised and alienated in the regulatory policymaking process for development compared to the higher levels of government (Olowu, 1981; Gboyega, 1987; Yahaya, 1989). This outcome likely stems from the habitual oppression of local governments by the superior tiers in the inter-government coordination schemes for actualising nationwide growth. Profound evidence abounds in Nigeria - and also throughout Africa - that the higher tiers usurp functions of the local administrations with high-end revenue returns thereby diminishing their internally generated revenues. In Nigeria, state governments often appropriate federal allocations of the local administrations (Adeyemi, 2013). This explains why the local administrations across Africa habitually depend on financial handouts and solicit aid from the higher tiers to carry out their exclusive functions. What eventually evolves from the scenario painted above is a dysfunctional national development index due to the abject contribution and nonconstructive involvement of the local governments in the development administration. The national underdevelopment index of Nigeria for instance is worsened too by recurring recourse to fiscal, political, functional and administrative centralisation policy matrix in development administration, as well as further subordination of local autonomy in the coordination of even projects that naturally come under a truly grassroots development category. Unfortunately, the outcomes of suppressed local administrations in the intergovernmental relations processes to advance social, economic and political growth continues to be poor national development indicators.

\section{Research Objectives and Questions}

The main objectives of the paper are to determine what published scholarly research works between 2010 and 2020 proffer as the reasons why local governments in Nigeria underperform in the nationwide developmental curve and to propose reform agendas that require to be pursued to enhance their contributions to overall national inclusive growth of African countries. 
Therefore, the research questions that the paper addresses are what reasons are being proffered in published works of literature between 2010 and 2020 about Nigeria's local governments' underperformances in the nationwide developmental trajectory of the country? And what reform proposals need to be pursued to enhance their contributions to the overall national inclusive growth of African countries?

\section{Methodology}

The paper's orientation aligns with the qualitative methodology based on critical literature review analysis. The paper evaluates published works of literature partly to highlight the usefulness of the literature review methodology in qualitative research as a method that reliably supports the promotion of valid theory-building (Bandara, Furtmueller, Gorbacheva, Miskon \& Beekhuyzen, 2015). In the paper, the adopted methodological orientation is anchored on works of literature constructed on various types of review processes mostly the critical, integrative, systematic mapping meta-analysis, and mixedmethods designs. By implication, our adopted methodology based on literature review analysis aligns the paper to be both of a inductive and deductive reasoning. That is, it aids theory-building by deducing what studies report about our subject matter by "extracting and synthesizing the voices of scholars from a data-driven approach" (Bandara et al, 2015) and inducting the data as the basis of making recommendations.

\section{Sampling Method}

Purposeful sampling as utilised here involves a selection of informed works of literature based on a self-conceived and cognitive decision of the researchers (cf. Suri, 2011). The choice of the study period (2010-2020) is justifiable on two grounds. The first is to ensure that contemporary knowledge of the reasons why local administrations are undercontributing to national development in Nigeria is emphasised and analysed. Second is that the published works of literature within the understudied period concerning the focus of the paper have greater potential to suggest functional reform agenda that African governments will require to project and execute to enhance local governments' roles in national development.

\section{Thematic Coding}

In the paper, Vaismoradi, Jones, Turunen and Snelgrove (2016) and Williams and Moser's (2019) explicated coding technique was adopted to evolve the thematic codes. For instance, Williams and Moser (2019) explicate these coding techniques: open, axial and selective coding in the arranged order. The open coding of our paper is the first stage of coding. It involves the identification of broad themes prevalent in the scholarly discourses about the notions of the classical theorists of local government. Our open coding has been described in the meta-theoretical underpinning section of the paper. The axial coding, being the second stage of the thematic coding of the paper, highlighted the generated 
three thematic codes that guided the sampling of works of literature as the analyzed data. The axially generated codes are a) optimization of local governance, b) enhancement of local democracy, and c) facilitation of efficient local services delivery. The third stage of Williams and Moser's explicated coding which the paper applied is selective coding which involves a sample of eventually analyzed works of literature. This is reflected in ensuing sections.

\section{Data Analysis Method}

In this paper, the applied data analysis tool is the directed thematic content analysis which involves a focused summative and interpretive approach to thematic codes vis-à-vis sampled data (Assarroudi, Nabavi, Armat, Ebadi, \& Vaismoradi, 2018). This entails the interpretation of data in relation to the themes that were evolved from the open and axial coding stages and the selection cum sampling coding stage of works of literature. The interplay of conventional (inductive reasoning), directed (deductive reasoning) and summative (interpretative reasoning) were at work to evolve a valid and reliable explication and answering of our research questions. Furthermore, our directed thematic content analysis approach enabled an inclusive integrated discussion section that elaborates on the analyzed works of literature as they relate to the African-wide context. Ultimately, this data analysis approach aids the trustworthiness of the paper's discussion and recommended reform agendas it suggests.

\section{Data Analysis}

\begin{tabular}{|l|l|}
\hline Theme & $\begin{array}{l}\text { Meta-analysis of works of literature between 2 } \\
2020 \text { of Nigerian Context }\end{array}$ \\
\hline Optimisation of local governance & $\begin{array}{l}\text { According to Diejomaoh and Eboh (2012:1), t } \\
\text { challenge of poverty eradication in Nigeri } \\
\text { sustaining local administrations that have } \\
\text { accountability deficit, and have a deficiency in } \\
\text { capacity issues". Gilbert and Barigbon (2015 } \\
\text { noted that lack of effective participation, plar } \\
\text { coordination with other tiers in dev } \\
\text { administration as well as the absence of local a } \\
\text { and undue interference by higher tiers in local gc } \\
\text { bedevils optimal local administrations' devel } \\
\text { mindset. Tony (Ed., 2011) agrees that espe } \\
\text { confidence and financial corruption of Nige } \\
\text { governments do distance a developmental } m \\
\text { them and this extricates an inclusive } \\
\text { transformation to happen from the bottom of } \\
\text { levels to the top echelons of governance. } \\
\text { constitutional subordination of local go } \\
\text { functions, finances and administration }\end{array}$ \\
\hline
\end{tabular}




\begin{tabular}{|c|c|}
\hline & $\begin{array}{l}\text { government directions has proven to undern } \\
\text { government operations and thereby de-legit } \\
\text { local tiers' contribution to the overall develo } \\
\text { Nigeria (Adeyemo, 2011; Otinche, 2014; Okudol } \\
\text { al). Owolabi (2015) holds that the Niger } \\
\text { governments' operations are antithetical to } \\
\text { development. }\end{array}$ \\
\hline Enhancement of local democracy & $\begin{array}{l}\text { Chukwuemeka, Ugwuanyi, Ndubuisi and Onuo } \\
\text { have noted that democratisation advancement } \\
\text { is slow due to subordination of local political } \\
\text { and local self-government especially } \\
\text { governments, instead of by credible election } \\
\text { representatives. Abdulhamid and Chima (2015) } \\
\text { absence of local democracy impacts nega } \\
\text { Nigeria's democratisation drive. Ibietan anc } \\
\text { (2014) aver that sustainable devolution of } \\
\text { autonomy and sustenance of local democ } \\
\text { positively impact on development and democra } \\
\text { Nigeria. Researchers such as Oruonye (201 } \\
\text { Osakede and Owolabi (2015) and Akpan anc } \\
\text { (2013) hold that constitutional amendments to } \\
\text { local politico cum democratic autonomy will } \\
\text { Nigeria's grassroots democracy vis-à-vis the } \\
\text { democratisation. A key challenge of federal sta } \\
\text { democratic advancement in Nigeria lay in local } \\
\text { that usually deliver overwhelming victories to } \\
\text { parties of the state governments (Akpan \& Ekan } \\
\text { Oyedele, Osezua, Abdulkareem \& Ishola, 2017; } \\
\text { Onah, 2019). }\end{array}$ \\
\hline Facilitation of local service delivery & $\begin{array}{l}\text { Adeyemi (2013) stresses the view that Nige } \\
\text { governments lack autonomy and therefor } \\
\text { translate whatever decentralisation programme } \\
\text { no matter how idealistic and humane those poli } \\
\text { to actualise. Chukwuemeka, Ugwuanyi, Ndu } \\
\text { Onuoha (2014) argue that appropriation of the } \\
\text { revenues and allocations of local governments } \\
\text { is the major militating factor why that governm } \\
\text { cannot provide optimum public infrastructur } \\
\text { and services to enhance living standards of loca } \\
\text { Isa (2016) and Chidiebere and Ndaguba ( } 201 \\
\text { implementable decentralisation policies from t } \\
\text { low participation of community dwellers in sett } \\
\text { agendas, and imposition of state-based project }\end{array}$ \\
\hline
\end{tabular}




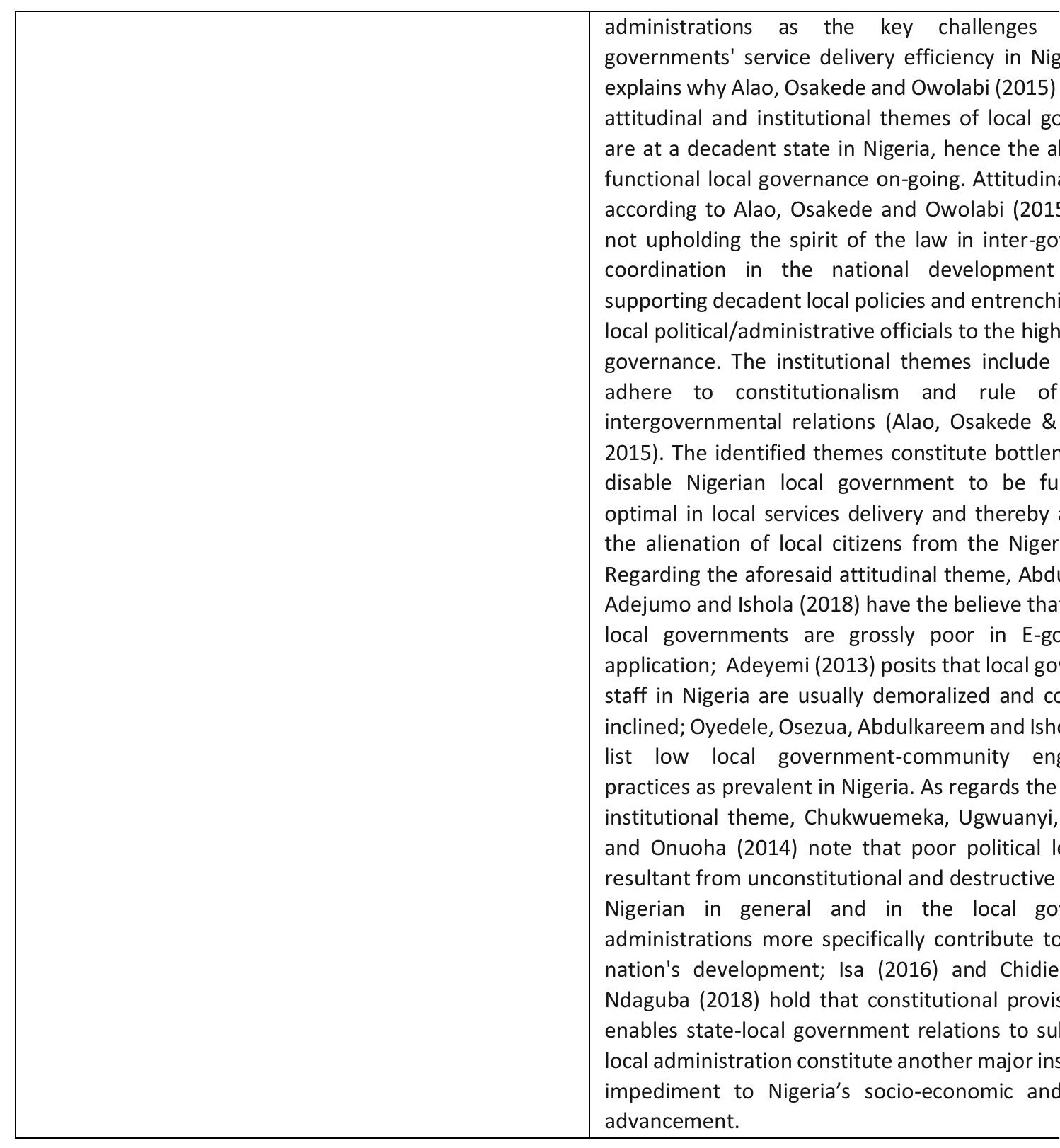

\section{Discussions and Lessons for African nations}


Most African nations suffer strains to development and good governance arising from various militating factors to nation-building such as overt ethnicity, militancy, insurgency, terrorism, political corruption and spills from a long period of military rule. These militating factors usually cause re-centralisation and place greater responsibilities on federal/national/central governments to reign over-development course. For instance, the Arab Spring is believed to result from a depressed local administration considering its initial point of evolution before spreading to other North African nations. North African nations have long years of centralised-military rules and experiences of long-lasting individualpersonal and military-centralised authoritarian regimes. Thus, North Africa portrays a region with high rate of dictatorships. What this implies is that there persists a high rate of centralised system of governance. Hence, local governments in the region are often subordinated to the central government thereby implying the absence of local autonomy.

Immense constraints to nation-building for development resultant from political, ethnic and religious mistrust prevails in the Eastern Africa region and Central African region. These social negations cause further recourse to centralisation of the development process in these regions. Take for instance, the killings in the Central African Republic; the mayhems from Kenya's contested national elections and every form of militancy and ethnicity induced struggles over natural resources and political power grabs via civil wars experienced in Angola, Rwanda, Southern Sudan, amongst others indicate the diminishment of local autonomy and decentralisation practices. In these instances, local governments' participation in curtailing these nation-building defilers is minimal as intergovernmental transfers (administrative duties, finances, and functions) to the local administration to purposively contribute to the solution are often very insignificant. Experience shows that during these turmoil in these regions, local government does formally exist in name but is actually eroded in terms of its functions.

In the Southern Africa and West African regions, reforms to strengthen local autonomy and decentralisation have been undertaken in one form over the last two decades within these regions. However, these reforms are often poorly articulated to improve local autonomy and decentralisation. The institutional architecture upon which these reforms rest hardly supports local self-government in service delivery and grassroots democratisation. For example, in most West African countries, local government's functional, political, administrative and fiscal autonomy is by constitutional dictum relegated under state government legislative competency under the residual constitutional responsibilities. A good example is in Nigeria that Section 197(1)(b) \& B(4-a) of the operating 1999 Constitution establishes State Independent Electoral Commission of which is empowered "to organize, undertake and supervise elections to local government councils within the state". We argue that a local poll wherein the state government's ruling party will partake in and is constitutionally empowered to organize cum govern violates the ex-ante indeterminacy quality of the democratic philosophy and thereby will 
undermine grassroots democracy and political autonomy ultimately. The ex-ante indeterminacy theme is understood as that outcome of a credible election that ought not to be so predetermined as to grant incumbent ruling parties purview to defeat other competing opposition parties in the local election. Empirically, candidates of the ruling state regimes usually win overwhelmingly in the local elections they organize. By Constitutional dictate, intergovernmental fiscal transfers for development to municipal administrations in South Africa, Zimbabwe, Lesotho, Swaziland and most other Southern Region countries tie the local government too much to the aprons of both national and provincial/state governments than local self-government's efforts.

Given the above views, African nations need to institute and manage the intergovernmental relations schemes for development such as to facilitate effective delivery of local services and utilities for local areas by the local administrations. Similarly, administrative autonomy needs to be pursued such that the local government staff function within an organisational system, procedure and structure that enables the local administrators to meet their duties and obligations for grassroots development (democratic, economic, social and political obligations) under a cordial working relationship with the higher tiers and not oppressed or compelled to work for the advantages of political elites at the central/state levels. Substantial consideration needs to be given to fiscal and political autonomy. Decentralisation laws, programmes and policies ought not to erode local capacity to manage its tax revenues and expenditure functions without undue usurpation of their revenue earning avenues by the higher tiers. The political autonomy of local governments can only be sustained if local elections are organised by a body not under the direction of state governments like a federal government's instituted commission.

Our analysis shows that absence of local autonomy and poor decentralisation approaches dampens cordial intergovernmental relations. Also, dysfunctional decentralisation approaches allow suffocation of local autonomy and such leads to domination of the local government tier. For instance, political and fiscal decentralisation programmes ought to support local administrations to be accountable to the local electorates and not political elites at the top levels of government. Reforms should essentially promote accountability and probity to local citizens first and foremost and not to party elites either at the local levels or the higher tiers. Every reform frameworks need to support bottom-up approaches to the development of Africa state qua state such as to enable the institution of strong local governance systems and functional local political institutions. The aforesaid observations are the basic elements that the classical theory of local government proposes as the purpose for instituting local administrations to be involved in the national development trajectory.

\section{Concluding Remarks}


In a synopsis, in concord with the supposition of this paper, the contemporary view that optimal national development cannot come about if political elites do not support the important role of constructive local government input to the general developmentbuilding process is a reality. By this reality, the paper makes its modest contribution to the contemporary debate about Africa's development process, emphasizing that the actualisation of optimal development in Africa lies in critical sustenance of local autonomy and promotion of functional decentralisation programmes. For emphasis, the fiscal, political, functional and administrative autonomy of local governments in the intergovernmental decentralisation policy arrangements for advancement of African socio-political formations is a salient element for development and therefore should not be toyed with by the political elites in the higher echelons of government.

\section{References}

Abdulhamid, O. S. and Chima, P. (2015). Local Government Administration. The Search for Relevance. Commonwealth Journal of Local Government, Vol. 18, pp. 181-195. Accessed from https://search.informit.org/doi/pdf/10.3316/informit.897716366008753

Abdulkareem, A. K., Adejumo, A. and Ishola, A. A. (2018). Local Government Internally Generated Revenue and Administrative Costs: A Question of Efficiency. Journal of Techno Social, Vol. 10, No. 2, pp. 22-28.

Adeyemi, O. (2013). Local Government and the Challenges of Service Delivery: The Nigerian Experience. Journal of Sustainable Development in Africa, Vol. 15, No. 7, pp. 8494.

Adeyemo, D. (2011). Optimizing Local Government Finance through Public-Private Partnership. In O. Tony [Ed.] Key Issues in Local Government and Development: A Nigerian Perspective. Enugu: Praise House Publishers.

Aghayere, V. O. (1997). Dominant Issues in Nigerian Local Government System: A Contemporary Focus. Benin City: Imprint Services.

Aghayere, V. O. (1999). Introduction to Local Government. Social Sciences Monograph Series No. 6, Lagos: Imprint Services.

Akpan, F. and Ekanem, O. (2013). The Politics of Local Government Autonomy in Nigeria. European Scientific Journal, Vol. 9, No. 35, pp.193-205.

Alao, D. O., Osakede, K. O. and Owolabi, T. Y. (2015). Challenges of Local Government Administration in Nigeria: Lessons from Comparative Analysis. International Journal of Development and Economic Sustainability, Vol. 3, No. 4, pp. 61-79. 
Andrew, C. and Goldsmith, M. (1998). From Local Government to Local Governance - and Beyond. International Political Science Review, Vol. 19, No. 2, pp.101-117.

Assarroudi, A., Nabavi, F. H., Armat, M. R., Ebadi, A. and Vaismoradi, M. (2018). Directed Qualitative Content Analysis: The Description and Elaboration of its Underpinning Methods and Data Analysis Process. Journal of Research in Nursing, Vol. 23, No. 1, pp. 42-55.

Atakpa, M., Ocheni, S. and Nwankwo, B.C. (2012). Analysis of Options for Maximizing Local Government Internally Generated Revenue in Nigeria. International Journal of Learning and Development, Vol. 2, No. 5, pp. 94-105.

Awotokun, K. (2005). Local Government Administration under the 1999 Constitution in Nigeria. Journal of Social Sciences, Vol. 10, Issue 2, pp. $129-134$.

Bandara, W., Furtmueller, E., Gorbacheva, E., Miskon, S. and Beekhuyzen, J. (2015).

Achieving Rigor in Literature Reviews: Insights from Qualitative Data Analysis and Tool-Support. Communications of the Association for Information Systems, Article 37, No. 8.

Bradshaw, G., Breakfast, N. B., and Nomarwayi, T. (2016). Violent Service Delivery Protests

- The Challenge of Maintaining Law and Order: A Case of the Nelson Mandela Bay

Municipality. Journal of Public Administration, Vol.51, No.3, pp.408-422.

Brinkerhoff, D. and Crosby, B. (2002). Managing Policy Reform: Concepts and Tools for Decision-Makers in Developing and Transitioning Countries. Bloomfield, CT: Kumarian Press, Inc.

Chidiebere, O. A. and Ndaguba, E. A. (2018). Selected Difficulties Towards Effective Service Provision in Nigerian Local Government. Journal of Social Sciences, Special Issue, pp. 1-9.

Chukwuemeka, E., Ugwuanyi, B. I., Ndubuisi-Okolo, P. and Onuoha, C. E. (2014). Nigerian Local Government: A Discourse on the Theoretical Imperatives in a Governmental System. African Research Review: An International Multidisciplinary Journal, Ethiopia, Vol. 8(2), Serial No. 33, pp. 305-324.

Dale, A., Robinson, J., King, L., Burch, S., Newell, R., Shaw, A. and Jost, F. (2020). Meeting the Climate Change Challenge: Local Government Climate Action in British Columbia, Canada. Climate Policy, Vol. 20, No. 7, pp. 866-880.

Diejomaoh, I. and Eboh, E. (2012). Local Government in Nigeria: Relevance and Effectiveness in Poverty Reduction and Economic Development. (April 24, 2012). Available at SSRN: https://ssrn.com/abstract=2045439 or http://dx.doi.org/10.2139/ssrn.2045439 
Fieldman, L. and Goldrick, M. (1970). Politics and Government of Urban Canada. Toronto: Methuem.

Gboyega, A. (1987). Political Values and Local Government in Nigeria. Lagos: Malthouse Press Limited.

George, V. and Miller, S. (Ed., 2013). Social Policy Towards 2000: Squaring the Welfare Circle. New York: Routledge.

Gilbert, L. D. and Barigbon, C. B. (2015). The Politics of Poverty in Democratic Participation: Nigeria in Perspective. Developing Country Studies, Vol. 5, No. 18, pp. 114-123.

Gray, A. and Jenkins, B. (1999). Democratic Renewal in Local Government: Continuity and Change. Local Government Studies, Vol. 25, No. 4, pp. 26-45.

Holden, E., Linnerud, K. and Banister, D. (2017). The Imperative of Sustainable Development. Sustainable Development, Vol. 25, pp. 213-226.

Ibaba, I. S. (2011). Local Government and Failure of Rural Development in Nigeria: Explaining the Role of Political Participation. Journal of Social Development in Africa, Vol.26, Issue 2, pp. 18-24.

Ibietan, J. and Ndukwe, P. (2014). Local Government Administration in Nigeria and the Localist Theory: Exploring the Nexus. Studies in Social Sciences and Humanities, Vol. 1, No. 4, pp. 130-139.

Isa, M. K. (2016). Nigerian Local Government System and Governance: Lessons, Prospects and Challenges. In E.D. Schoburgh, Y. J. Martin \& S. Gatchair (Eds.) Developmental Local Governance: A Critical Discourse in Alternative Development. UK: Palgrave Macmillan.

Iyoha, F. E. (1996). Some Aspects of Public Administration and Policy in Nigeria. Benin City: Sylva Publication Limited.

Ladner, A. and Keuffer, N. (2018). Creating an Index of Local Autonomy - Theoretical, Conceptual, and Empirical Issues. Regional and Federal Studies, DOI: 10.1080/13597566.2018.1464443

Mackenzie, W. J. M. (1961). Theories of Local Government. Greater London Papers No. 2, a London School of Economics Publication.

Mill, John Stuart (1861). Consideration on Representative Government. London: Parker Son, and Bourn, West Strand.

Okudolo, I. T. P. (2017). Constitutional Contradictions and the Implications on State-Local Government relations in Nigeria, 1999-2015. Unpublished Ph.D. Thesis of the Department of Political Science, University of Lagos. 
Okudolo, P. T. I. (2018). "Local Government Autonomy and Revenue Generation in Nigeria: A Critical Review of the Kaduna State Tax (Codification and Consolidation) Law 2016" in Ilorin Journal of Administration and Development, Vol 4, No. 2, pp. 12-19. Okudolo, P. T. I. and Onah. I. E. (2019). Efficient Local Government and the Stability of Federalism in Nigeria. African Renaissance, Vol.16, Issue 3, pp.11-25.

Okudolo, P.T. I. \& Ojakorotu, V. (2021). "Behavioural Prognosis for Enabling Operative Primary Healthcare during COVID-19 in Africa: Debriefing South Africa-Nigeria Policy Norms" in V. Ojakorotu and B. Olajide (Eds.) Proceedings on the Conference on the Implications of COVID-19 on Gender and Behaviour in Africa. Pp. 35-42. Published by The Havilah Glo Marketing.

Okonjo, I. M. (1974). British administration in Nigeria 1900 - 1950: A Nigerian view. New York: NOK Publishers. Oruonye, E. D. (2013). Grassroots Democracy and the Challenges of Rural Development in Nigeria. A Case Study of Bali Local Government Area of Taraba State. Asian Journal of Humanities and Social Sciences, Vol. 1, Issue 1, pp. 12-19.

Oyedele, S. O., Osezua, E. M., Abdulkareem, A. K. and Ishola, A. A. (2017). Local Government Administration and National Development in Nigeria: Challenges and Prospects. Ilorin Journal of Human Resources Management, Vol. 1, Issue 1, pp. 13. Romeo, L. G. (2012). Decentralization for Development: The Developmental Potential of Local Autonomy and the Limits of Politics-Driven Decentralization Reforms. Working Paper No. 11, Publication of the Swedish International Centre for Democracy.

Scot, A. (2017). Making Governance Work for Water-Energy-Food Nexus Approaches. Working Paper of the Climate and Development Knowledge Network (CDKN). Access from https://media.africaportal.org/documents/Workingpaper CDKN Making-governance-work.pdf

Ola, R. F. (1984). Local Administration in Nigeria. London: Kegan Paul International Publishers.

Olowu, D. (1981). Strategies for Decentralization within Developing Countries: A Nigerian Case Study. In L. Adamolekun, D. Oluwo \& M. Laleye (Eds.) Local Government in West Africa Since Independence. Lagos: Lagos University Press.

Otinche, S. I. (2014). Fiscal Policy and Local Government Administration in Nigeria. African Research Review: An International Multidisciplinary Journal Ethiopia, Vol. 8, Issue 2, Serial No. 33, pp. 118-137. 
Oyediran, O. and Gboyega, A. (1979). Local Government and Administration. In O. Oyediran (Ed.) Nigerian Government and Politics under Military Rule. London: Macmillan Press.

Sharpe, L. J. (1970). Theories and Values of Local Government. Political Studies, Vol.18, Issue 2, pp. 153 -174.

Suri, H. (2011). Purposeful Sampling in Qualitative Research Synthesis. Qualitative Research Journal, Vol. 11, No. 2, pp.63-75.

Swilling, M. (2008). Local Governance and the Politics of Sustainability. In M. van Donk, M. Swilling, E. Pieterse \& S. Parnell (Eds.) Consolidating Developmental Local Government: Lessons from the South African Experience. An Isandla Institute Book Project/UTC Press, Cape Town, South Africa.

Tony, O. [Ed.] (2011). Key Issues in Local Government and Development: A Nigerian Perspective. Enugu: Praise House Publishers.

Vaismoradi, M., Jones, J., Turunen, H. and Snelgrove, S. (2016). Theme Development in Qualitative Content Analysis and Thematic Analysis. Journal of Nursing Education and Practice, Vol. 6, No. 5, pp. 100-110.

Whalen, H. (1960). Ideology, Democracy and the Foundation of Local-self Government. Canadian Journal of Economics and Political Science, Vol. 26, No. 3, pp. 377-395.

Williams, M. and Moser, T. (2019). The Art of Coding and Thematic Exploration in Qualitative Research. International Management Review, Vol. 15, No. 1, pp. 4555.

Yahaya, A. D. (1981). Local Government in Nigeria: The 1976 Organization. In O. Oyediran (ed) Survey of Nigerian Affairs 1976-77. Lagos: Macmillan Publishers.

Yahaya, A. D. (1989). Local Government Reforms: The Military Initiative. In P. Ekeh, P. DeleCole \& G.O. Olusanya (Eds.), Nigeria Since Independence: The First 25 Years (Vol. V): Politics and Constitutions. Nigeria: Heinemann Educational Books Limited. 